\section{RSP}

http://www.rsp.fsp.usp.br/

Revista de

Saúde Pública

\title{
Use of the Brazilian People's Pharmacy Program by older adults
}

\author{
Vanessa Iribarrem Avena Miranda', Anaclaudia Gastal Fassa', Rodrigo Dalke Meucci", \\ Bárbara Heather Lutz"
}

' Programa de Pós-Graduação em Epidemiologia. Faculdade de Medicina. Universidade Federal de Pelotas. Pelotas, RS, Brasil

" Departamento de Medicina Social. Faculdade de Medicina. Universidade Federal de Pelotas. Pelotas, RS, Brasil

\section{ABSTRACT}

OBJECTIVE: To assess the prevalence and factors associated with the use of the expanded Brazilian People’s Pharmacy Program among older adults and the reasons for not using it.

METHODS: In this population-based cross-sectional study conducted in the urban area of Pelotas, RS, Southern Brazil, we evaluated 1,305 older adults (aged 60 years or over) who had used medication in the last 15 days. Independent variables were socioeconomic factors, economic status, household income in minimum wages, educational attainment in years of schooling and occupational status. Demographic variables were sex, age, marital status, and self-reported skin color/race. Poisson regression was employed to analyze the factors associated with the use of the program.

RESULTS: The prevalence of use was $57.0 \%$ whilst the prevalence of knowledge of the program was $87.0 \%$. In individuals aged 80 years or over, use of the program was $41.0 \%$. As to the origin of the prescriptions used by older adults, $46.0 \%$ were from the Brazilian Unified Health System. The main reasons for not using the program were: difficulty in getting prescriptions, medication shortage, and ignorance about the medications offered and about the program. Higher age, lower income, presence of chronic diseases, and use of four or more medications were associated with use of the program.

CONCLUSIONS: It is necessary to expand the knowledge and use of the Brazilian People's Pharmacy Program, especially among older adults, and to improve the dissemination of its list of medications to users and physicians. Thus it will be possible to reduce spending on long-term medications, which are especially important for this population.

DESCRIPTORS: Aged. Community Pharmacy Services. Equity in Access. Drug Utilization. Pharmacoepidemiology. Cross-Sectional Studies.

Received: 10 Feb 2015

Approved: 31 May 2015

How to cite: Miranda VIA, Fassa AG, Meucci RD, Lutz BH. Use of the Brazilian People's Pharmacy Program by older adults. Rev Saude Publica 2016;50:13.

Copyright: This is an open-access article distributed under the terms of the Creative Commons Attribution License, which permits unrestricted use, distribution, and reproduction in any medium, provided that the original author and source are credited.

Vanessa Iribarrem Miranda Centro de Pesquisas

Marechal Deod

96020-220 Pelotas, RS, Brasil E-mail: vanessairi@gmail.com 
a Ministério da Saúde, Secretaria de Políticas de Saúde. Política Nacional de Medicamentos: informe técnico institucional. Brasília (DF); 2000.

${ }^{\mathrm{b}}$ Ministério da Saúde. Programa Farmácia Popular do Brasil: manual básico. Brasília (DF); 2005.

cMinistério da Saúde, Secretaria de Ciência, Tecnologia e Insumos Estratégicos, Departamento de Assistência Farmacêutica e Insumos Estratégicos. Programa Farmácia Popular do Brasil: manual de informações às unidades credenciadas: sistema de co-pagamento. 2.ed. Brasília (DF); 2008

${ }^{\mathrm{d}}$ Brasil. Decreto $\mathrm{n}^{\circ}$ 5.090, de 20 de maio de 2004. Regulamenta a Lei $n^{\circ} 10.858$, de 13 de abril de 2004, e institui o programa "Farmácia Popular do Brasil" e dá outras providências. Brasília (DF); 2004 [cited 2015 Sept 16]. Available from: http://www.planalto.gov.br/ ccivil_03/_ato2004-2006/2004/ decreto/d5090.htm

e Ministério da Saúde. Portaria $n^{\circ} 749$, de 15 de abril de 2009. Dispõe sobre a expansão do Programa Farmácia Popular do Brasil - Aqui Tem Farmácia Popular. Brasília (DF); 2009 [cited 2015 Sept 16]. Available from: http://bvsms.saude.gov. br/bvs/saudelegis/gm/2009/ prt0749_15_04_2009.html

${ }^{\text {f}}$ Portal Brasil. Gratuidade de medicamentos beneficia 14 milhões de pessoas. Brasília (DF); 2013 [cited 2013 Mar]. Available from: http://www.brasil.gov.br/ governo/2013/02/gratuidadede-medicamentos-beneficia-14milhoes-de-pessoas.

${ }^{8}$ Ministério da Saúde. Portaria $\mathrm{n}^{\circ}$ 1.146, de $1^{\circ}$ de junho de 2012. Altera e acresce dispositivos à Portaria $n^{\circ}$. 971/GM/MS, de 17 de maio de 2012, para ampliar a cobertura da gratuidade no âmbito do Programa Farmácia Popular do Brasil. Brasília (DF); 2012 [cited 2015 Sept 16].

Available from: http://bvsms.saude. gov.br/bvs/saudelegis/gm/2012/ prt1146_01_06_2012.html ${ }^{\text {h}}$ World Health Organization. Envelhecimento ativo: uma política de saúde. Brasília (DF): Organização Pan-Americana da Saúde; 2005 [cited 2015 Sept 16]. Available from: http://bvsms. saude.gov.br/bvs/publicacoes/ envelhecimento_ativo.pdf

\section{INTRODUCTION}

Ensuring access to basic and essential medications to all individuals is a priority in today's health policies ${ }^{13, a}$. The Federal Government launched in 2004 the Programa Farmácia Popular do Brasil (PFPB - Brazilian People's Pharmacy Program) as part of the Brazilian Unified Health System (SUS) b,c,d. This strategy aims to promote the expansion of access to medication and equal service ${ }^{\mathrm{b}}$ to the entire population. The purpose is to avoid treatment quitting, especially by individuals with low income who use private health services, but have difficulty in buying the required medications in regular drugstores ${ }^{20, e}$.

The PFPB develops two axes of action: its own network of people's pharmacies and the Aqui tem Farmácia Popular (People’s Pharmacy Here) extended network (PFPB-E). People's Pharmacies, in operation since 2004, dispense 112 medications at cost value, representing a reduction of up to $90.0 \%$ of the market value. The PFPB-E, considered an expansion of the PFPB in partnership with private pharmacies and drugstores, was created with the goal of broadening the coverage of pharmaceutical assistance, promoting the integrality of health care $^{5}$. In this mode, the Ministry of Health (MS) subsidizes $90.0 \%$ of the reference value for medication for diseases such as dyslipidemia, Parkinson's disease, glaucoma, osteoporosis and rhinitis, in addition to birth control and adult diapers. In 2011, with the creation of the Saúde Não Tem Preço (Health is Priceless) program, the two axes of action began dispensing free medication for asthma, diabetes and hypertension".

Although the program is directed to all age groups, it is especially important for older adults, who tend to have bigger health needs, resulting in increased use of health services and medications ${ }^{5,19, \mathrm{~h}}$. In this sense, the PFPB-E helps control and prevent chronic diseases, increasing the population's access to medical therapy and reducing the impact of medication cost on family budgets ${ }^{3}$.

As the PFPB is relatively new, studies about it are scarce and give greater emphasis to its own network, which was consolidated first. They are restricted to describing the program in terms of medication availability compared with the public and private sectors and the profile of the population that uses the program ${ }^{8,14,15}$. Although this study addresses the PFPB only on the private network, since there are no program units in the city of Pelotas, this is the first population-based study to obtain information on the use of the PFPB-E for each medication ${ }^{\mathrm{i} . j}$.

Considering the importance of the universalization of access to medications for population health and the role of the PFPB to expand access, we aimed to assess the prevalence and factors associated with the use of the PFPB-E among older adults and the reasons for not using it.

\section{METHODS}

This population-based cross-sectional study was performed with older adults (aged 60 years or over) in the urban area of Pelotas, RS, Southern Brazil. There are approximately 46,099 older adults in the urban area of this city (2010 Demographic Census, IBGE) data from the local health surveillance, there are about 165 pharmacies and drugstores in Pelotas, of which $62.0 \%$ are linked to the PFPB-E. This study is part of research "Avaliação da saúde de idosos da cidade de Pelotas”, conducted in the first semester of 2014.

The sample size estimation to study the prevalence of the use of the PFPB-E considered the following parameters: $95 \%$ confidence level, $60.0 \%$ estimated prevalence, tolerable error of four percentage points, and an increase of $10.0 \%$ for losses and refusals. To assess the factors associated with the outcome, the parameters used were: $95 \%$ confidence level, $80.0 \%$ minimum statistical power, 1:5 ratio between unexposed and exposed, 48.0\% estimated prevalence for the unexposed, 1.3 prevalence ratio, an increase of $15.0 \%$ for confounding factors, and 1.5 design effect, totaling an estimated sample size of 1,246 older adults. 
i Ferreira RL. Análise de implantação do Programa Farmácia Popular do Brasil no Rio de Janeiro e no Distrito Federal: um estudo de casos [dissertation]. Rio de Janeiro (RJ): Escola Nacional de Saúde Pública Sergio Arouca da Fundação Oswaldo Cruz; 2006.

¡Junges F. Avaliação do Programa Farmácia Popular do Brasil: aspectos referentes a estrutura e a processos [dissertation]. Porto Alegre (RS): Faculdade de Farmácia da Universidade Federal do Rio Grande do Sul; 2009.

${ }^{\mathrm{k}}$ Instituto Brasileiro de Geografia e Estatística. Censo demográfico 2010: Cidades: Rio Grande do Sul: Pelotas. Rio de Janeiro; s.d.[cited 2014 Dec 5]. Available from: http://cidades.ibge.gov.br/ painel/painel.php?lang $=\& \operatorname{codmu}$ $\mathrm{n}=431440$ \&search $=$ |pelotas

'Associação Brasileira de Empresas de Pesquisa - ABEP. Critério de Classificação Econômica Brasil - CCEB 2012: Base LSE 2010. Available from: http://www.abep.org/criterio-brasil
Sample selection was performed in two stages. In the first, the 488 census districts of Pelotas were listed and sorted according to average income, with a random sampling of 133 districts. This strategy ensured the inclusion of several neighborhoods of different economic status. In the second stage, occupied households in the selected districts were counted, estimating about one older adult for every three households. We drew 31 households by district, with the aim of reducing design effects, and sampled approximately 10 households in each selected district, totaling 4,123 households. All people aged 60 years or over in each household were invited to participate in the study. We excluded those living in nursing homes, unable to answer the questionnaire for mental or physical issues, and who lacked a companion or caregiver.

The outcome "use of the PFPB" was defined as obtaining at least one medication from the PFPB among older adults who had used any medication in the last 15 days. "Knowledge of the PFPB" was checked by answering yes to the question "Do you know the People's Pharmacy Program?"

When respondents reported not obtaining the medication from the PFPB-E or SUS pharmacies (municipal or primary health care units), they were asked if they had tried to. In case of an affirmative answer, they were asked the reasons for failing to get the medication and, in case of a negative answer, why they had not sought the PFPB-E. The packaging or prescription of every medication used was requested to verify the correct names and later classify them by pharmacological groups. To trace the origin of prescriptions, the following question was made: "Who prescribed this medication for you?" (SUS physician or dentist; private or health plan physician or dentist).

The independent variables were: socioeconomic factors; economic status, classified according to the Brazilian Association of Market Research Companies (ABEP) ${ }^{1}$ (Social Classes A or $\mathrm{B}$; C; D or E), categorized household income in minimum wages $(\leq 1 ; 2-3 ; 4-5 ; 6-9 ; \geq 10)$, educational attainment in years of schooling (none; up to three years; four to seven years, eight to 10 years; 11 or more) and occupational status (working; retired or receiving the social security disability insurance; retired and working; homemaker or unemployed). Demographic variables were sex (male; female), age in years according to four categories (60-64; 65-69; 70;-79; $\geq 80$ ), marital status (with a partner; without a partner) and self-reported skin color/race (white; nonwhite).

To describe the sample according to morbidities, the medical diagnosis reported by the respondent was characterized as: diabetes, hypertension, respiratory diseases (asthma; bronchitis; emphysema), rhinitis, glaucoma, Parkinson's disease, dyslipidemia, and osteoporosis. The need for using long-term medication was assessed by the question "Do you need to take any long-term medication? Consider long-term medication as those you use regularly without a date to stop". The number of medications used by the older adult in the last 15 days $(1,2,3$, and $\geq 4)$ was also assessed. Social support was considered present if older adults had someone to help with their needs.

Thirteen trained interviewers visited the selected households to deliver a study presentation letter explaining it and inviting older adults to participate. After eligible individuals' acceptance, interviews were scheduled according to their availability. Electronic questionnaires with precoded questions were applied using netbooks.

We considered as losses and refusals the interviews not conducted after three attempts, one of those by a study supervisor. Quality control was performed by the field supervisor with $10.0 \%$ of respondents selected at random. We used a shorter version of the questionnaire, composed of 19 questions. Correlation was analyzed by the kappa index.

Analyses were performed in the Stata 12.1 program. The sample was described in relation to the independent variables, and the prevalence of the outcome "use of the PFPB-E" was estimated with the respective confidence intervals for individuals who had used any medication in the last 15 days. To estimate the prevalence of reasons for not using the program, we utilized a stratified analysis by age. 
Table 1. Description of the sample of older adults who had used medications in the last 15 days according to demographic and socioeconomic variables stratified by age. Pelotas, RS, Southern Brazil, 2014. ( $N=1,305)$

\begin{tabular}{|c|c|c|c|c|c|c|c|c|c|}
\hline \multirow{2}{*}{ Variable } & \multirow{2}{*}{$\mathbf{n}^{\mathrm{a}}$} & \multirow{2}{*}{$\%$} & \multirow{2}{*}{$95 \% \mathrm{Cl}$} & \multicolumn{2}{|c|}{ 60-79 years } & \multirow{2}{*}{$95 \% \mathrm{Cl}$} & \multicolumn{2}{|c|}{$\geq 80$ years } & \multirow{2}{*}{$95 \% \mathrm{Cl}$} \\
\hline & & & & $\mathbf{n}$ & $\%$ & & $\mathbf{n}$ & $\%$ & \\
\hline \multicolumn{10}{|l|}{ Age } \\
\hline $60-64$ & 345 & 26.5 & $24.1-28.9$ & - & - & - & - & - & - \\
\hline $65-69$ & 321 & 24.7 & $22.3-27.0$ & - & - & - & - & - & - \\
\hline $70-79$ & 418 & 32.1 & $29.6-34.7$ & - & - & - & - & - & - \\
\hline$\geq 80$ & 217 & 16.7 & $14.6-18.7$ & - & - & - & - & - & - \\
\hline \multicolumn{10}{|l|}{ Sex } \\
\hline Male & 459 & 35.2 & $32.6-37.8$ & 388 & 35.8 & $32.9-38.6$ & 70 & 32.3 & $25.9-38.5$ \\
\hline Female & 846 & 64.8 & $62.2-67.4$ & 696 & 64.2 & $61.3-67.0$ & 147 & 67.7 & $61.4-74.0$ \\
\hline \multicolumn{10}{|l|}{ Marital status } \\
\hline Living without a partner & 620 & 47.6 & $44.9-50.3$ & 468 & 42.6 & $39.6-45.5$ & 158 & 72.8 & $66.8-78.7$ \\
\hline Living with a partner & 682 & 52.4 & $49.7-55.1$ & 624 & 57.4 & $54.4-60.3$ & 59 & 27.2 & $21.2-33.1$ \\
\hline \multicolumn{10}{|l|}{ Skin color/Race } \\
\hline Nonwhite & 205 & 15.8 & $13.8-17.7$ & 167 & 15.2 & $13.1-17.3$ & 40 & 18.4 & $13.2-23.6$ \\
\hline White & 1,097 & 84.2 & $82.3-86.2$ & 925 & 84.8 & $82.6-86.9$ & 177 & 81.6 & $76.3-86.7$ \\
\hline \multicolumn{10}{|c|}{ Educational attainment (in years of schooling) } \\
\hline 0 & 176 & 13.6 & $11.7-15.5$ & 120 & 11 & $9.16-12.9$ & 57 & 26.6 & $20.7-32.6$ \\
\hline$\leq 3$ & 288 & 23.1 & $20.7-25.3$ & 244 & 22.5 & $20.0-24.9$ & 56 & 26.2 & $20.2-32.1$ \\
\hline $4-7$ & 391 & 30.2 & $27.7-32.7$ & 339 & 31.2 & $28.3-33.8$ & 56 & 26.2 & $20.2-32.1$ \\
\hline $8-10$ & 132 & 10.2 & $8.5-11.8$ & 122 & 11.2 & $9.4-13.2$ & 10 & 4.7 & $1.8-7.5$ \\
\hline$\geq 11$ & 296 & 22.9 & $20.6-25.2$ & 261 & 24.1 & $21.6-26.7$ & 35 & 16.3 & $11.3-21.3$ \\
\hline \multicolumn{10}{|l|}{ Occupational status } \\
\hline Working & 89 & 7.4 & $5.9-8.8$ & 90 & 8.8 & $6.9-10.4$ & 1 & 0.5 & $-0.05-1.5$ \\
\hline $\begin{array}{l}\text { Retired or receiving the social } \\
\text { security disability insurance }\end{array}$ & 871 & 72.0 & $69.5-74.6$ & 705 & 69.2 & $66.3-72.0$ & 169 & 87.1 & $82.3-91.8$ \\
\hline Retired and working & 125 & 10.3 & $8.6-12.1$ & 117 & 11.2 & $9.4-13.3$ & 10 & 5.2 & $2.0-8.2$ \\
\hline Homemaker or unemployed & 124 & 10.3 & $8.5-11.9$ & 111 & 10.8 & $8.9-12.7$ & 14 & 7.2 & $3.5-10.9$ \\
\hline \multicolumn{10}{|l|}{ Economic classification - ABEP } \\
\hline$A$ or $B$ & 449 & 36.4 & $33.7-39.1$ & 373 & 36.3 & $33.3-39.2$ & 76 & 36.7 & $30.0-43.3$ \\
\hline $\mathrm{C}$ & 639 & 51.8 & $49.0-54.6$ & 544 & 52.9 & $49.8-55.9$ & 98 & 47.3 & $40.5-54.2$ \\
\hline $\mathrm{D}$ or $\mathrm{E}$ & 145 & 11.8 & $9.9-13.5$ & 111 & 10.8 & $8.9-12.7$ & 33 & 16.0 & $10.9-21.0$ \\
\hline \multicolumn{10}{|l|}{ Income in minimum wages } \\
\hline$\leq 1$ & 125 & 10.3 & $8.6-12.0$ & 105 & 10.4 & $8.4-12.2$ & 19 & 9.4 & $5.3-13.5$ \\
\hline $2-3$ & 519 & 42.7 & $39.8-45.4$ & 445 & 43.7 & $40.6-46.7$ & 77 & 38.3 & $31.5-45.1$ \\
\hline $4-5$ & 257 & 21.1 & $18.8-23.4$ & 207 & 20.3 & $17.8-22.8$ & 51 & 25.4 & $19.3-31.4$ \\
\hline $6-9$ & 177 & 14.5 & $12.6-16.5$ & 142 & 13.9 & $11.9-16.2$ & 35 & 17.4 & $12.1-22.7$ \\
\hline$\geq 10$ & 139 & 11.4 & $9.6-13.2$ & 119 & 11.7 & $9.6-13.6$ & 19 & 9.5 & $5.3-13.5$ \\
\hline \multicolumn{10}{|l|}{ Social support ${ }^{\mathrm{b}}$} \\
\hline No & 96 & 7.4 & $6.0-8.8$ & 84 & 7.8 & $6.2-9.4$ & 11 & 5.1 & $6.1-9.4$ \\
\hline Yes & 1,205 & 92.6 & $91.2-94.0$ & 997 & 92.2 & $90.6-93.8$ & 205 & 94.9 & $90.6-93.8$ \\
\hline \multicolumn{10}{|l|}{ Knowledge of the PFPB } \\
\hline No & 165 & 12.6 & $10.8-14.5$ & 101 & 9.3 & $7.6-11.0$ & 62 & 28.7 & $22.6-34.8$ \\
\hline Yes & 1,139 & 87.4 & $85.5-89.1$ & 984 & 90.7 & 88.9-92.4 & 154 & 71.3 & $65.2-77.4$ \\
\hline \multicolumn{10}{|l|}{ Use of the PFPB-E } \\
\hline No & 534 & 43.2 & $40.4-45.9$ & 408 & 39.8 & $36.8-42.8$ & 123 & 58.8 & $52.1-65.6$ \\
\hline Yes & 703 & 56.8 & $54.1-59.6$ & 616 & 60.2 & $57.2-63.2$ & 86 & 41.2 & $34.4-47.9$ \\
\hline
\end{tabular}

Continue 
Table 1. Description of the sample of older adults who had used medications in the last 15 days according to demographic and socioeconomic variables stratified by age. Pelotas, RS, Southern Brazil, 2014. ( $N=1,305)$. Continuation

\begin{tabular}{|c|c|c|c|c|c|c|c|c|c|}
\hline \multicolumn{10}{|c|}{ Number of medications used } \\
\hline 1 & 163 & 12.5 & $10.7-14.3$ & 144 & 13.3 & $11.2-15.3$ & 17 & 7.8 & $4.2-11.4$ \\
\hline 2 & 203 & 15.6 & $13.6-17.5$ & 174 & 16.1 & $13.8-18.2$ & 28 & 12.9 & $8.4-17.4$ \\
\hline 3 & 234 & 17.9 & $15.8-20.0$ & 200 & 18.4 & $16.1-20.8$ & 33 & 15.2 & $10.4-20.0$ \\
\hline$\geq 4$ & 705 & 54.0 & $51.3-56.7$ & 566 & 52.2 & $49.2-55.2$ & 139 & 64.1 & $57.6-70.5$ \\
\hline \multicolumn{10}{|c|}{ Need for long-term medication } \\
\hline No & 68 & 5.2 & $4.0-6.4$ & 60 & 5.5 & $4.2-6.9$ & 8 & 3.7 & $1.1-6.2$ \\
\hline Yes & 1,237 & 94.8 & $93.6-96.0$ & 1,024 & 94.5 & $93.1-95.8$ & 209 & 96.3 & 93.8-98.8 \\
\hline \multicolumn{10}{|c|}{ Health conditions variables } \\
\hline \multicolumn{10}{|c|}{ Diabetes } \\
\hline No & 973 & 74.6 & $72.3-76.9$ & 802 & 73.9 & $71.4-76.6$ & 169 & 77.9 & $72.3-83.4$ \\
\hline Yes & 331 & 25.4 & $23.0-27.7$ & 282 & 26.1 & $23.4-28.6$ & 48 & 22.1 & $16.6-27.7$ \\
\hline \multicolumn{10}{|c|}{ Hypertension } \\
\hline No & 371 & 28.5 & $26.0-30.9$ & 309 & 28.7 & $26.0-31.5$ & 61 & 28.2 & $22.2-34.3$ \\
\hline Yes & 933 & 71.5 & $69.1-74.0$ & 766 & 71.3 & $68.5-73.9$ & 155 & 71.7 & $65.7-77.8$ \\
\hline \multicolumn{10}{|c|}{ Chronic respiratory diseases } \\
\hline No & 1,077 & 82.7 & $80.7-84.8$ & 905 & 83.6 & $81.4-85.8$ & 169 & 77.9 & $72.3-83.4$ \\
\hline Yes & 225 & 17.3 & $15.2-19.3$ & 177 & 16.4 & $14.2-18.6$ & 48 & 22.1 & $16.5-27.6$ \\
\hline \multicolumn{10}{|c|}{ Rhinitis } \\
\hline No & 1,037 & 79.7 & $77.5-81.9$ & 857 & 80.2 & $77.8-82.6$ & 177 & 82.7 & $77.6-87.8$ \\
\hline Yes & 264 & 20.3 & $18.1-22.5$ & 211 & 19.8 & $17.4-22.1$ & 37 & 17.3 & $12.2-22.4$ \\
\hline \multicolumn{10}{|c|}{ Glaucoma } \\
\hline No & 1,201 & 92.3 & 90.9-93.8 & 1,010 & 93.3 & $91.9-94.8$ & 188 & 88.3 & 83.9-92.6 \\
\hline Yes & 100 & 7.7 & $6.2-9.1$ & 72 & 6.7 & $5.2-8.1$ & 25 & 11.7 & $7.3-16.1$ \\
\hline \multicolumn{10}{|c|}{ Parkinson's disease } \\
\hline No & 1,280 & 98.3 & $97.6-99.0$ & 1,068 & 98.7 & 98.0-99.4 & 209 & 96.3 & $93.8-98.9$ \\
\hline Yes & 22 & 1.7 & $0.9-2.3$ & 14 & 1.3 & $0.06-1.9$ & 8 & 3.7 & $1.1-6.2$ \\
\hline \multicolumn{10}{|c|}{ Dyslipidemia } \\
\hline No & 733 & 56.2 & $53.5-58.9$ & 594 & 55.3 & $52.3-58.3$ & 137 & 63.7 & $52.2-70.2$ \\
\hline Yes & 570 & 43.8 & $41.0-46.4$ & 480 & 44.7 & $29.8-42.7$ & 78 & 36.3 & $29.8-42.7$ \\
\hline \multicolumn{10}{|c|}{ Osteoporosis } \\
\hline No & 954 & 73.3 & $70.9-75.7$ & 809 & 75.5 & $72.9-78.0$ & 142 & 65.7 & $59.4-72.1$ \\
\hline Yes & 347 & 26.7 & $24.3-29.1$ & 263 & 24.5 & $21.9-27.1$ & 74 & 34.3 & $27.9-40.6$ \\
\hline
\end{tabular}

ABEP: Brazilian Association of Market Research Companies; PFPB: Brazilian People's Pharmacy Program; PFPB-E: Brazilian People's

Pharmacy Program - expansion model

a The maximum number of ignored values was 96, for occupational status.

b Social support: possibility of the older adult.

The factors associated with the use of PFPB-E were analyzed by Poisson regression, using the svy command to consider the study design effect. Variables with $\mathrm{p}>0.2$ not were taken to adjusted analysis. Regression followed a hierarchical model of backward elimination, which comprises three levels. The distal level included demographic and socioeconomic variables; the second level, the presence of morbidities; and the proximal level, knowledge of the PFPB and the number of medications used. Wald tests were used for heterogeneity and linear trend for the categorical variables. Variables with $p<0.2$ were maintained in the model to control confounding factors. The significance level of 0.05 was considered.

To analyze the prevalence of PFPB-E use and associated factors, the total number of older adults who had used medication in the last 15 days was used as a denominator. To characterize medications (presence in the PFPB-E, classification by pharmacological group, gratuitousness of medications), total medications used were the denominator. 
This study was approved by the Research Ethics Committee of the Faculdade de Medicina of Universidade Federal de Pelotas (Opinion 472,357). All participants signed an informed consent form and were assured of the confidentiality of information given.

\section{RESULTS}

We interviewed 1,451 older adults. Losses and refusals totaled 21.3\% ( $\mathrm{n}=393)$, most of them women and aged 60-69 years. Of the interviews, $4.0 \%$ were answered by a caregiver or companion. Most older adults (90.5\%) had used at least one medication in the last 15 days. Among them, mean age was 70.9 years $(\mathrm{SD}=8.2), 64.8 \%$ were women, $84.2 \%$ were white, $52.4 \%$ lived with a partner, and $30.2 \%$ had four to seven years of schooling. The predominant occupational status was retired or receiving the social security disability insurance (72.0\%), 42.7\% had a household income of two to three minimum wages, and $51.8 \%$ were part of social class C (Table 1 ).

About of $93.0 \%$ of the older adults reported having someone to help them with their needs. Regarding self-reported health conditions, $25.4 \%$ had diabetes, $71.5 \%$ hypertension, and $17.3 \%$ respiratory diseases (Table 1 ).

The prevalence of PFPB-E use was $56.8 \%$ whilst the prevalence of knowledge of the program was $87.4 \%$. About of $95.0 \%$ of the older adults had to take long-term medication, and $54.0 \%$ used four or more medications (Table 1). Of the individuals reporting long-term use of medication and taking medication in the last 15 days, 53.9\% used the PFPB-E to obtain at least one medication (data not shown in tables). Considering age stratification, $71.3 \%$ of the people aged 80 years or over knew the PFPB, $41.2 \%$ had used the program and $64.1 \%$ used four or more medications (Table 1).

Table 2. Reasons for not using the Brazilian People's Pharmacy Program, by older adults who had not obtained all their medications from the PFPB-E or SUS in the last 15 days, according to age. Pelotas, RS, Southern Brazil, 2014. $(N=1,014)$

\begin{tabular}{|c|c|c|c|c|c|c|}
\hline \multirow{3}{*}{ Variable } & \multirow{2}{*}{\multicolumn{2}{|c|}{ General }} & \multicolumn{4}{|c|}{ Age group } \\
\hline & & & \multicolumn{2}{|c|}{$60-79$} & \multicolumn{2}{|c|}{$\geq \mathbf{8 0}$} \\
\hline & $\mathbf{n}$ & $\%$ & $\mathbf{n}$ & $\%$ & $\mathbf{n}$ & $\%$ \\
\hline \multicolumn{7}{|l|}{ Tried to obtain a medication from the PFPB-E } \\
\hline No & 462 & 45.6 & 356 & 42.8 & 105 & 58.3 \\
\hline Yes & 552 & 54.1 & 476 & 57.2 & 75 & 41.7 \\
\hline \multicolumn{7}{|l|}{ Reasons for trying and failing $(\mathrm{n}=552)$} \\
\hline Difficulty in going to the pharmacy & 31 & 5.7 & 20 & 4.2 & 9 & 12.3 \\
\hline Shortage of medication of the prescribed brand & 49 & 8.9 & 41 & 8.7 & 8 & 10.8 \\
\hline Medication shortage & 69 & 12.6 & 59 & 12.5 & 10 & 13.5 \\
\hline Difficulty in obtaining the prescription & 93 & 17.0 & 77 & 16.3 & 16 & 21.6 \\
\hline Medication is not in the PFPB list & 408 & 74.4 & 349 & 73.9 & 57 & 77.0 \\
\hline Other & 43 & 7.8 & 38 & 8.0 & 5 & 6.8 \\
\hline \multicolumn{7}{|l|}{ Reasons for not trying $(\mathrm{n}=469)$} \\
\hline Not trusting PFPB medication & 15 & 3.4 & 13 & 3.8 & 2 & 2.0 \\
\hline A physician advised against it & 16 & 3.6 & 13 & 3.8 & 3 & 3.0 \\
\hline Difficulty in going to the pharmacy & 34 & 7.6 & 18 & 5.2 & 16 & 16.2 \\
\hline Difficulty in obtaining the prescription & 55 & 12.3 & 43 & 12.5 & 12 & 11.9 \\
\hline Not knowing the PFPB & 128 & 28.6 & 85 & 24.6 & 43 & 42.2 \\
\hline Not knowing which medications are available in the PFPB & 174 & 39.1 & 127 & 36.9 & 47 & 47.0 \\
\hline Medication is not in the PFPB list & 185 & 45.7 & 155 & 48.6 & 30 & 35.3 \\
\hline Other reasons & 84 & 18.9 & 67 & 19.5 & 17 & 16.8 \\
\hline
\end{tabular}

PFPB-E: Brazilian People's Pharmacy Program - expansion model; SUS: Brazilian Unified Health System; PFPB: Brazilian People's Pharmacy Program 
Table 3. Factors associated with use of the People's Pharmacy Program in the last 15 days. Pelotas, RS, Southern Brazil, 2014.

\begin{tabular}{|c|c|c|c|c|c|c|c|c|c|}
\hline Level $^{\mathrm{a}}$ & Variable & $\mathbf{p}$ & $95 \% \mathrm{Cl}$ & $\mathbf{P R}_{\text {crude }}$ & $95 \% \mathrm{Cl}$ & $\mathbf{p}$ & $\mathbf{P R}_{\text {adjusted }}$ & $95 \% \mathrm{Cl}$ & $\mathbf{p}^{\mathbf{b}}$ \\
\hline \multirow{20}{*}{1} & Age & & & & & $<0.001$ & & & 0.004 \\
\hline & $60-64$ & 60.6 & $34.0-44.7$ & 1 & - & - & 1 & - & - \\
\hline & $65-69$ & 59.1 & $53.5-64.7$ & 0.97 & $86.3-1.10$ & - & 0.97 & $0.85-1.11$ & - \\
\hline & $70-79$ & 60.5 & $55.7-65.3$ & 0.99 & $87.7-1.14$ & - & 1.02 & $0.89-1.16$ & - \\
\hline & $\geq 80$ & 41.1 & $34.4-47.9$ & 0.67 & $56.3-81.9$ & - & 0.72 & $0.60-0.87$ & - \\
\hline & Educational attainment (in ye & ars of $s$ & oling) & & & 0.007 & & & 0.131 \\
\hline & 0 & 48.0 & $40.4-55.5$ & 1 & - & - & 1 & - & - \\
\hline & $\leq 3$ & 60.8 & $55.0-66.5$ & 1.26 & $1.03-1.55$ & - & 1.22 & $0.99-1.52$ & - \\
\hline & $4-7$ & 63.1 & $58.2-68.0$ & 1.31 & $1.06-1.62$ & - & 1.31 & $1.06-1.62$ & - \\
\hline & $8-10$ & 56.8 & $47.7-65.8$ & 1.18 & $0.93-1.50$ & - & 1.20 & $0.94-1.54$ & - \\
\hline & $\geq 11$ & 50.2 & $44.3-56.1$ & 1.05 & $0.84-1.30$ & - & 1.14 & $0.90-1.46$ & - \\
\hline & Income in minimum wages & & & & & $0.001^{\mathrm{c}}$ & & & $0.005^{c}$ \\
\hline & $\leq 1$ & 56.9 & $47.7-66.0$ & 1 & - & - & 1 & - & - \\
\hline & $2-3$ & 61.5 & $57.2-65.8$ & 1.08 & $0.90-1.30$ & - & 1.0 & $0.83-1.20$ & - \\
\hline & $4-5$ & 60.0 & $53.8-66.2$ & 1.05 & $0.86-1.30$ & - & 0.97 & $0.77-1.22$ & - \\
\hline & $6-9$ & 50.6 & $43.0-58.1$ & 0.88 & $68.7-1.15$ & - & 0.83 & $0.63-1.10$ & - \\
\hline & $\geq 10$ & 40.9 & $32.4-49.4$ & 0.72 & $0.55-0.94$ & - & 0.66 & $0.49-0.90$ & - \\
\hline & Marital status & & & & & 0.013 & & & 0.036 \\
\hline & Living without a partner & 52.6 & $48.5-56.6$ & 1 & - & - & 1 & - & \\
\hline & Living with a partner & 60.8 & $57.0-64.6$ & 1.16 & $1.03-1.30$ & - & 1.13 & $1.0-1.28$ & \\
\hline \multirow{15}{*}{2} & Hypertension & & & & & $<0.001$ & & & $<0.001$ \\
\hline & No & 38.0 & $32.6-43.4$ & 1 & - & - & 1 & - & \\
\hline & Yes & 63.2 & $60.0-66.3$ & 1.66 & $1.41-1.96$ & - & 1.52 & $1.29-1.77$ & \\
\hline & Diabetes & & & & & $<0.001$ & & & $<0.001$ \\
\hline & No & 52.7 & $49.4-55.9$ & 1 & - & - & 1 & - & \\
\hline & Yes & 68.1 & $63.0-73.1$ & 1.30 & $1.19-1.40$ & - & 1.19 & $1.09-1.30$ & \\
\hline & Dyslipidemia & & & & & $<0.001$ & & & $<0.001$ \\
\hline & No & 48.1 & $44.3-51.8$ & 1 & - & - & 1 & - & \\
\hline & Yes & 67.3 & $63.4-71.1$ & 1.40 & $1.27-1.54$ & & 1.31 & $1.20-1.43$ & \\
\hline & Glaucoma & & & & & 0.128 & & & 0.129 \\
\hline & No & 56.2 & $53.4-59.1$ & 1 & & & 1 & & \\
\hline & Yes & 63.9 & $54.2-73.6$ & 1.14 & $0.96-1.34$ & & 1.13 & $0.96-1.34$ & \\
\hline & Rhinitis & & & & & 0.050 & & & 0.05 \\
\hline & No & 55.4 & $52.3-58.5$ & 1 & - & - & 1 & & \\
\hline & Yes & 62.1 & $56.0-68.2$ & 1.12 & $1.0-1.25$ & - & 1.12 & $0.99-1.26$ & \\
\hline \multirow{8}{*}{3} & Knowledge of the PFPB & & & & & $<0.001$ & & & $<0.001$ \\
\hline & No & 16.4 & $10.2-22.6$ & 1 & - & - & 1 & - & - \\
\hline & Yes & 61.9 & $59.0-64.8$ & 3.77 & $2.63-5.40$ & - & 2.87 & $2.01-4.08$ & - \\
\hline & Number of medications used & & & & & $<0.001^{\mathrm{c}}$ & & & $<0.001^{c}$ \\
\hline & 1 & 37.5 & $28.7-46.3$ & 1 & - & - & 1 & - & - \\
\hline & 2 & 41.1 & $34.0-48.1$ & 1.09 & $80.3-1.49$ & - & 0.96 & $71.6-1.28$ & - \\
\hline & 3 & 53.5 & $46.9-60.0$ & 1.42 & $1.06-1.90$ & - & 1.22 & $92.0-1.62$ & - \\
\hline & $\geq 4$ & 65.6 & $62.0-69.1$ & 1.74 & $1.35-2.26$ & - & 1.40 & $1.07-1.80$ & - \\
\hline
\end{tabular}

PFPB: Brazilian People's Pharmacy Program

a All variables were controlled for the others of the same level and above, with $\mathrm{p}$ from 0.2 to 0.05 .

${ }^{\mathrm{b}}$ The variables with significance level from 0.05 to 0.2 were maintained in the model to control confounding.

c Wald Test for linear trend. 
Among the 1,014 older adults who had not acquired all their medications from the PFPB-E or directly from SUS units, $54.0 \%$ had tried obtaining them from the program. The main reasons reported for not having obtained medication from the program were the medication not being in the PFPB-E list (74.0\%), difficulty in getting the prescription (17.0\%), and medication shortage (13.0\%). Among those who did not try to get the medication from the PFPB-E, the main reasons were the medication not being in the PFPB-E list (46.0\%), ignorance of which medications were available (39.0\%) and no knowledge of the PFPB (29.0\%) (Table 2).

Of the people aged 80 years or over who had not obtained all their medications from the PFPB-E or SUS, $42.0 \%$ had tried to get the medications from the program. This age group had more difficulty in obtaining the prescription $(21.0 \%)$ and going to the pharmacy (12.0\%) than the $60-79$ years group ( $16.0 \%$ and $4.0 \%$, respectively). About $45.0 \%$ of them reported lacking knowledge of the program and medications available as a reason not to try obtaining the medication from the PFPB-E. Among older people aged 80 years or over, $16.0 \%$ reported difficulty in going to the pharmacy as a reason (Table 2).

Table 3 describes the factors associated with the use of the PFPB-E. The crude analysis showed no association with sex, skin color/race, occupation and social support. People aged 80 years or older presented a $28.0 \%$ lesser use of the PFPB-E than those aged 60-64 years, while those living with partners used it $13.0 \%$ more than those without a partner. The use of the program decreased linearly with increasing income, and individuals with household income equal to or greater than 10 minimum wages used the program $34.0 \%$ less than those of lower income.

Individuals with chronic diseases as diabetes, hypertension, and dyslipidemia used the program $19.0 \%, 52.0 \%$, and $31.0 \%$ more, respectively, than those without these morbidities. Older people who knew the PFPB used it three times more than those who did not, and individuals who took four or more medications used the PFPB-E $40.0 \%$ more than those who took only one medication (Table 3).

Table 4. Description of the medications in the PFPB-E list according to use of the program. Pelotas, RS, Southern Brazil, 2014. ( $N=1,873)$

\begin{tabular}{lcc}
\hline Medication obtained from the PFPB-E & $\mathbf{n}$ & $\%$ \\
\hline No & 599 & 32.4 \\
Yes & 1,249 & 67.6 \\
Medications obtained free of charge from the PFPB-E & & \\
No & 258 & 20.7 \\
Yes & 991 & 79.3 \\
Origin of the prescription of the medications obtained from the PFPB-E & & \\
SUS & 569 & 45.6 \\
Health plan or private & 678 & 54.4 \\
Description of the PFPB-E medications according to pharmacologic class & & \\
Respiratory diseases (asthma, bronchitis, emphysema) & 31 & 1.7 \\
Diabetes & 351 & 18.7 \\
Dyslipidemia & 327 & 17.5 \\
Glaucoma & 15 & 0.8 \\
Hypertension & 1,092 & 58.3 \\
Osteoporosis & 34 & 1.8 \\
Parkinson's disease & 13 & 0.7 \\
Rhinitis & 10 & 0.5 \\
\hline
\end{tabular}

PFPB-E: Brazilian People's Pharmacy Program - expansion model; SUS: Brazilian Unified Health System 
Of the 5,700 medications used by the older adults, $32.9 \%(n=1,873)$ were part of the PFPB-E; of these, $67.6 \%$ ( $n=1,249)$ were obtained from the program, of which $79.3 \%$ ( $n=991)$ free of charge. As to the origin of the prescription used to obtain the medications from the people's pharmacy, $54.4 \%$ were from private or health plan professionals. The most used medications by the PFPB-E, according to pharmacological classification, were antihypertensive drugs (58.3\%), antidiabetic drugs (18.7\%), and lipid modifying agents (17.5\%) (Table 4).

Among the medications used for chronic conditions such as respiratory diseases, diabetes, and hypertension, $41.9 \%, 85.2 \%$, and $58.9 \%$, respectively, were present in the PFPB-E list (data not shown in tables).

The design effect of this study was 1.14, the intra-class correlation coefficient was 0.0099 , and the kappa index of the variable "PFPB knowledge" presented good reproducibility (kappa $\geq 0.7)$.

\section{DISCUSSION}

Of the older people who used medications, more than $80.0 \%$ knew the PFPB and more than half used it. However, those aged 80 years or over used the program less. This shows that the program is very disseminated, except among the oldest adults. In addition, a significant portion of the older adults with prescriptions from SUS obtained medications from the PFPB-E, even though they are not its priority group.

In a 2008 population-based study in adults aged 20 years or over, knowledge of the PFPB was $32.8 \%^{8}$. The greater knowledge of PFPB in this study may result from the increased time between data collection and the beginning of the program or from the exclusive participation of older adults, who use medications and health services more, increasing the opportunities to learn about the program ${ }^{8,10}$.

The main barriers to the use of the program are lack of prescription, medication shortage, and the medication not being part of the program, suggesting difficulty of access to medical appointments and insufficient programming of medication supply and distribution. Although the number of medications offered by the program is great (including the vast majority of treatments for chronic conditions) and the list is revised periodically, it is necessary to assess whether the medications included in the program satisfy properly the treatment needs of the population 9 . On the other hand, the program includes medications similar to others that are not part of the program, indicating that physicians possibly fail to prioritize or to know the medications in the program ${ }^{1,16}$.

We also noted that difficulty in going to the pharmacy is a major problem for people aged 80 years or over since, in the absence of the patient, a legal representative is required to collect the medication. Although the existence of the program is widely known, there is still a lack of information, especially among people aged 80 years or over. The list of medications offered by the program is the least known aspect by the population.

Use of the PFPB-E was greater in the older adults aged less than 80 years. The reduction in the use of the program by people aged 80 years or over might reflect inequality in access to medications since as age increases, older adult tends to be more medicalized. This inequality might be related to inability or difficulty of mobility, which hinders access to medical appointments to renew the prescription and going to the registry to obtain the power of attorney required in case of a legal representative collecting the medication.

The study was consistent with the findings of Costa et al. ${ }^{8}$, who found no association between sex of respondents and use of the program. Women live longer, seek health services more ${ }^{2}$ and use more medications ${ }^{2,10,18}$. Thus, no association can be observed for the concentration of women in the 80 years or over group, which faces barriers to access the program. 
Individuals with partners used the PFPB-E more, which is consistent with the fact that individuals with partners use health services more ${ }^{7,8}$. Consequently, these individuals are more likely to diagnose diseases, to have access to prescriptions and to receive information regarding the $\mathrm{PFPB}$.

This study shows, consistently with the literature, that the program serves all socioeconomic strata of the population ${ }^{8,15}$. In addition, although most prescriptions used by the elderly to obtain the medications were from the private sector, the number of users of the public network is high, accounting for $46.0 \%$, in accordance with what Pinto et al..$^{14,15}$ found in their research.

A 2007 case study including municipalities from the five regions of Brazil suggests that users may have sought the program because of the ready availability of medications and its shorter wait. Centralizing medication purchasing can reduce pharmaceutical assistance costs, but the fact that medications for asthma, diabetes, and hypertension are available free of charge in the PFPB does not exempt state and municipal managers from the continuity of their provision. They should be available in primary health care pharmacies, facilitating the access for SUS users ${ }^{\mathrm{m}}$. Thus, failures in the free-of-charge provision of medications by municipal public networks overloads the demand of the PFPB-E, creating costs for the user, both with medications not covered by the program and with transportation to the pharmacy.

Medication shortage in the public and private sectors (PFPB-E) implies a greater part of users' income destined to health expenditure, which is already extremely high. The situation is even more complicated for those who fail to adhere to the treatment for the lack of money to purchase medication, which often worsens their health status ${ }^{4}$.

In accordance with previous studies ${ }^{6,11,15,17}$, the most used PFPB medications were those for cardiovascular conditions and those related to metabolism. That can be partly explained by the fact that these medications are available free of charge and by their consumption pattern, which reflects the profile of the chronic diseases most prevalent among older adults ${ }^{5,12}$.

The studied sample is representative of the older population residing in urban areas. Losses were not substantially different from the studied population, which reinforces the internal validity. As this study addressed only the PFPB private networks, its results can be generalized to municipalities with these characteristics. To better qualify the outcome characterization, we requested the packaging or prescription of all medications listed by the respondents. The lack of other household surveys concerning the PFPB-E limited the consistency analysis of this study.

The results obtained by this population survey expand knowledge regarding the use of the PFPB-E by the older population and of the reasons for not using it. Thus, they contribute to defining policies to qualify the program. People aged 80 years or over present a great need for access to medications and, according to the Brazilian Institute of Geography and Statistics (IBGE), the number of people in this age group increased by $70.0 \%$ from 2000 to $2010^{\mathrm{n}}$. This situation requires measures to reduce the inequality in the pharmaceutical assistance to this age group as well as to expand the use of the program. Expanding home care can contribute to this end, facilitating the obtaining of the prescription. However,

${ }^{\mathrm{m}}$ Ministério da Saúde. Crescimento do Programa Farmácia Popular. Brasília (DF); 2013 [cited 2014 Mar]. Available from: http://www.cosemsms.org. br/ultimas-noticias/farmaciapopular-nota-de-esclarecimento ${ }^{n}$ Instituto Brasileiro de Geografia e Estatística. Censo demográfico e contagem da população. Rio de Janeiro (RJ); 2014. Available from: http://www.sidra.ibge.gov. $\mathrm{br} / \mathrm{bda} / \mathrm{tabela}$ considering the mobility difficulties characteristic of this population group, it is critical to study alternatives to the requirement of power of attorney for legal representatives to receive medication from the pharmacy.

Disseminating the list of medications offered by the program both for the population and for physicians is necessary. This knowledge can contribute to increasing the use of the program by older adults and to health professionals, whenever possible, directing the prescription to medications in the list, reducing expenditure on long-term medications, which are especially important for this population ${ }^{1,9}$. 
The PFPB added an enormous cost to pharmaceutical assistance with the currently available medications and the gratuitousness of the most used medications for asthma, diabetes and hypertension. A PFPB medication can cost up to $290.0 \%$ more for the Brazilian Ministry of Health than for the Farmácia Básica (Primary Pharmacy)․

It is crucial that local authorities take responsibility for the pharmaceutical assistance of SUS users, promoting access to medication and the effective insertion of pharmaceutical assistance as a health action, especially for those in remote areas, with a medication supply closer to the user. This strategy is crucial to avoid spending on medications and transportation, and even low adherence to treatment in the low-income population.

\section{REFERENCES}

1. Aziz MM, Calvo MCM, d'Orsi E. Medicamentos prescritos aos idosos em uma capital do Sul do Brasil e a Relação Municipal de Medicamentos. Cad Saude Publica. 2012;28(1):52-64. DOI:10.1590/S0102-311X2012000100006

2. Bertoldi AD, Barros AJD, Hallal PC, Lima RC. Utilização de medicamentos em adultos: prevalência e determinantes individuais. Rev Saude Publica. 2004;38(2):228-38. DOI:10.1590/S0034-89102004000200012

3. Bertoldi AD, Barros AJ, Camargo AL, Hallal PC, Vandoros S, Wagner A et al. Household expenditures for medicines and the role of free medicines in the Brazilian public health system. Am J Public Health. 2011;101(5):916-21. DOI:10.2105/AJPH.2009.175844

4. Boing AC, Bertoldi AD, Peres KG. Desigualdades socioeconômicas nos gastos e comprometimento da renda com medicamentos no Sul do Brasil. Rev Saude Publica. 2011;45(5):897-905. DOI:10.1590/S0034-89102011005000054

5. Coelho Filho JM, Marcopito LF, Castelo A. Perfil de utilização de medicamentos por idosos em área urbana do Nordeste do Brasil. Rev Saude Publica. 2004;38(4):557-64. DOI:10.1590/S0034-89102004000400012

6. Costa HS, Borba ERC, Vilanova CM, Costa DM, Coutinho DF. Programa Farmácia Popular do Brasil: evolução do programa na cidade de São Luís - MA. Rev Pesq Saude. 2010;11(3):16-9.

7. Costa JSD, Reis MC, Silveira Filho CV, Linhares RS, Piccinini F. Prevalência de consultas médicas e fatores associados, Pelotas (RS), 1999-2000. Rev Saude Publica. 2008;42(6):1074-84. DOI:10.1590/S0034-89102008005000060

8. Costa KS, Francisco PMSB, Barros MBA. Conhecimento e utilização do Programa Farmácia Popular do Brasil: estudo de base populacional no município de Campinas, SP. Epidemiol Serv Saude. 2014;23(3):397-408. DOI:10.5123/S1679-49742014000300003

9. Dal Pizzol TS, Trevisol DJ, Heineck I, Flores LM, Camargo AL, Köenig A et al. Adesão a listas de medicamentos essenciais em municípios de três estados brasileiros. Cad Saude Publica. 2010;26(4):827-36. DO:10.1590/S0102-311X2010000400024

10. Flores VB, Benvegnú LA. Perfil de utilização de medicamentos em idosos da zona urbana de Santa Rosa, Rio Grande do Sul, Brasil. Cad Saude Publica. 2008;24(6):1439-46. DOI:10.1590/S0102-311X2012000100006

11. Inocencio M, De Vivo B. Acesso a medicamentos: análise das estratégias do estado para o desenvolvimento do Programa Farmácia Popular. Cad Gestao Publica Cidadania. 2011;16(59):201-21. DOI:10.12660/cgpc.v16n59.3700

12. Loyola Filho AI, Uchoa E, Firmo JOA, Lima-Costa MF. Estudo de base populacional sobre o consumo de medicamentos entre idosos: Projeto Bambuí. Cad Saude Publica. 2005;21(2):545-53. DOI:10.1590/S0102-311X2005000200021

${ }^{\circ}$ Carraro WBWH.

Desenvolvimento econômico do Brasil e o Programa Aqui Tem Farmácia Popular: limitantes e potencialidades [these]. Porto Alegre (RS): Faculdade de Ciências Econômicas da UFRGS; 2014.
13. Machado CV, Baptista TWF, Nogueira CO. Políticas de saúde no Brasil nos anos 2000: a agenda federal de prioridades. Cad Saude Publica. 2011;27(3):521-32. DOI:10.1590/S0102-311X2011000300012

14. Pinto CB, Miranda ES, Emmerick IC, Costa Ndo R, Osório-de-Castro CGS. Preços e disponibilidade de medicamentos no Programa Farmácia Popular do Brasil. Rev Saude Publica. 2010;44(4):611-9. DOI:10.1590/S0034-89102010005000021 
15. Pinto CB, Costa NR, Osório-de-Castro CG. Quem acessa o Programa Farmácia Popular do Brasil? Aspectos do fornecimento público de medicamentos. Cienc Saude Coletiva. 2011;16(6):2963-73. DOI:10.1590/S1413-81232011000600034

16. Portela AS, Leal AAF, Werner RPB, Simões MOS, Medeiros ACD. Políticas públicas de medicamentos: trajetória e desafios. Rev Cienc Farm Basica Apl. 2010;31(1):9-14.

17. Ruppenthal LR, Petrovick PR. Comparação do perfil dos usuários e dos medicamentos dispensados na Farmácia Popular do Brasil e em drogaria privada em Porto Alegre, Brasil. Latin Am J Pharm. 2010;29(1):22-9.

18. Silva GOB, Gondim APS, Monteiro MP, Frota MA, Meneses ALL. Uso de medicamentos contínuos e fatores associados em idosos de Quixadá, Ceará. Rev Bras Epidemiol. 2012;15(2):386-95. DOI:10.1590/S1415-790X2012000200016

19. Travassos C, Viacava F, Pinheiro R, Brito A. Utilização dos serviços de saúde no Brasil: gênero, características familiares e condição social. Rev Panam Salud Publica. 2002;11(5-6):365-73. DOI:10.1590/S1020-49892002000500011

20. Trevisan L, Junqueira LAP. Gestão em rede do SUS e a nova política de produção de medicamentos. Saude Soc. 2010;19(3):638-52. DOI:10.1590/S0104-12902010000300015

Funding: Programa de Excelência Acadêmica (PROEX) da Coordenação de Aperfeiçoamento de Pessoal de Nível Superior (CAPES - Process 23038.003968/2013-99).

Author's Contribution: Literature review, project preparation, all stages of fieldwork, data analysis and article drafting: VIAM. Project preparation, data analysis and article drafting: RDM. Participation in the fieldwork, database preparation and data analysis: BHL. Guidance of all stages of the research and review of the final article: AGF.

Acknowledgments: To Marília Guttier, for the support in the building of the medication database.

Conflict of Interest: The authors declare no conflict of interest. 